\section{Education in Germany}

By A. W. Fletcher. Pp. vi +61 . (Cambridge: W. Heffer and Sons, Ltd.; London: Simpkin Marshall, Ltd., 1934.) 2s. $6 d$. net.

Mr. Fletcher offers no eriticisms of national socialism. His book is a brief report. The general impression we get is that German schools are more courageous than those of Great Britain in revising and pruning their curricula, and that the overcrowded, unco-ordinated curriculum is giving way to an ordered group of subjects around the theme of the "development of mankind", studied in longer and less hurried school periods.

Mr. Fletcher tells of the influence of and parallel progress with English reformers: the influence of the Abbotsholme idea-morning, intellectual work; afternoon, sport or manual work; evening, "artistic performances"-multiple-option schools ousting classical education, parents' conferences --in Germany, in the community schools (elementary) - but both secondary school systems are examination-ridden.

Looking more deeply we discover the German methods of directly aiding the right development of character. Mr. Fletcher's report is rather one-sided. Of the intellectual side he only tells us that the place of religious teaching is as yet unsettled, as indeed it is with us. He also stresses the encouragement of free discussion among pupils and teachers and his references to the ridicule of Germany and France of the prefect system, very naturally, specially of the licence to cane other boys, reminds us that that system in England is often too laxly or too severely supervised to make it of genuine value to the boys.

Germany is ahead of us in supplying her elementary schools with teachers of university education.

The other part of character development, in common with other educational reforms, owes much to the youth movement, the training of the body "as a means of spiritual expression".

The account of the farm school near Berlin is among the more attractive items in the book.

Under national socialism we are told that the tendencies outlined in this book have been hurried forward, a serious study of biology begun and the claims of the Fatherland emphasised.

If we visited German schools we might not, like Mr. Fletcher, welcome the use of the newspaper as a school book.

\section{An Introductory Course in College Physics}

By Prof. Newton Henry Black. Pp. ix +714. (New York: The Macmillan Co., 1935.) 15s. net.

AMERICAN introductory courses in college physics are offered to students whose needs and earlier training differ considerably from those of most students of the same age at English universities. Prof. Black has written his book to cover a one-year course for university students who have not previously studied the subject or have, at most, done the three-term physics course customary at many American schools. He has taken care to eliminate mathematical difficulties not essential to his exposition of particular physical principles. Nothing more than the simplest mathematical knowledge is assumed or needed. The book therefore is quite unlike the text-books used for advanced classes in English secondary schools or for pass degrees at universities; here it has become customary to assume that the student has already done a science course for three years, and that he has acquired or is acquiring a knowledge of more advanced algebra and calculus.

There is considerable resemblance to the 'Everyday Physics' used in many English schools, but the subject is carried further in a form suited to rather more mature students. There are many pictures illustrating details of scientific and domestic apparatus and a considerable number of portraits of men of science with brief biographical details. The book should therefore be compared with other American surveys of physics such as those of Kimball and of Saunders. The type and the quality of the illustrations and plates call for special praise. The text is pleasant to read and gives an up-to-date review of the main principles of the subject, introducing the neutron in its brief explanations of atomic structure. The reviewer misses the admirable summaries of modern theory which distinguished Saunders's book, but the author has expressly stated that he has confined himself to what can be done in one year with beginners.

This work and the earlier one by Prof. Saunders ("A Survey of Physics", Holt and Co., 1930) are well worth places in the science libraries of English secondary schools.

\section{Scouting and Nature:}

for Scouts, Guides, Schools and Hikers. By Martin Baker. Pp. 136. (Glasgow: Brown, Son and Ferguson, Ltd., 1935.) 1s. 6d. net.

THIs is a small book, but within its well-written and well-illustrated 136 pages it contains a two-fold purpose which it should go far to achieve, namely, on one hand, that of strengthening and popularising the Scout movement by emphasising one of its most attractive activities, and, on the other hand, of inculcating a better and more intelligent appreciation of Nature. Nature study properly carried out in the true spirit of the Scouts affords wide scope for exploration and adventure, especially when undertaken with the stimulating guidance of such capable and well-informed leaders as Mr. Martin Baker.

Here we have a series of delightful rambles in the more remote haunts of Nature-on the lonely shore, the bleak uninhabited moorland and hill country, in the depths of great forests, or wild and picturesque valleys; followed by many attractive pages of archæological lore simply and eloquently presented, in which the past of this little island of ours lives again. The author, without any pretence at profound or specialised knowledge, of which we believe he has more than he cares to admit, is surely a born naturalist and keen observer, with the gift of describing what he sees. With the rapidly growing momentum of the hiking and camping movement, the need for a little book of this kind, from the point of viow of bird protection and much else, is abundantly evident. 